\title{
Seasonal Geochemical Trends and Pollution Assessment of Bottom Sediments in the São Francisco Hydrographic Basin, Brazil: The Três Marias Reservoir
}

\section{Gustavo Filemon Costa Lima ( $\sim$ gustavofilemon2@gmail.com )}

UFMG IGC: Universidade Federal de Minas Gerais Instituto de Geociencias https://orcid.org/0000-0003-3793-4395

Ciro Couto Bento

UFVJM: Universidade Federal dos Vales do Jequitinhonha e Mucuri

\section{Adolf Heinrich Horn}

UFMG IGC: Universidade Federal de Minas Gerais Instituto de Geociencias

\section{Eduardo Duarte Marques}

Serviço Geológico do Brasil: CPRM

\section{Hernando Baggio Filho}

UFVJM: Universidade Federal dos Vales do Jequitinhonha e Mucuri

\section{Research Article}

Keywords: Environmental assessment of Três Marias, Upper São Francisco basin, Geoaccumulation Index, Pollution Load Index, Sediments from the Três Marias Reservoir, Seasonal assessment, Tropical watershed, Seasonal geochemical background of Três Marias Reservoir.

Posted Date: June 25th, 2021

DOI: https://doi.org/10.21203/rs.3.rs-587585/v1

License: (c) (1) This work is licensed under a Creative Commons Attribution 4.0 International License. Read Full License

Version of Record: A version of this preprint was published at Environmental Science and Pollution Research on January 29th, 2022. See the published version at https://doi.org/10.1007/s11356-021-17878-5. 


\section{Abstract}

The Três Marias Reservoir is the ninth-largest reservoir in Brazil, becoming crucial for national strategic development. However, many anthropic activities may affect the sediment quality, promoting the need for a proper environmental assessment. This research appraised the seasonal influences on the Três Marias Reservoir's sediments geochemistry, elucidating possible anthropogenic impacts. The concentrations of $\mathrm{Mg}, \mathrm{Al}, \mathrm{Ca}, \mathrm{Cr}, \mathrm{Fe}, \mathrm{Co}, \mathrm{Cu}, \mathrm{Cd}, \mathrm{Ti}, \mathrm{Mn}, \mathrm{Ni}, \mathrm{Zn}, \mathrm{Ba}, \mathrm{Pb}$, and Organic matter were measured in 78 samples of bottom sediments regarding the two seasons of the area, a dry winter and rainy summer. The Median \pm 2 MAD (Median Absolute Deviation) settled the geochemical background for the two seasons. The sediment quality guidelines CONAMA 344/12 highlight the possible adverse ecological effects of pollutants. Hierarchical Clustering Analysis, Geoaccumulation index, and the Pollution Load Index delineated the polluted zones. The Pollution Load Index ranges from 0.25 to 2.28 in the dry season and 0.56 to 2.11 in the rainy season, defining three affected zones in the reservoir. Forestry and agriculture are the probable pollution sources, reaching warning levels that should be considered in further environmental strategies.

\section{Introduction}

The evaluation and monitoring of Potential Toxic Elements (PTEs) are fundamental in terms of environmental sustainability and human health safety (Srikanth et al. 2014). A geochemical assessment of PTEs in sediments is crucial to understand potential hazards to aquatic ecosystems once it can work as a geochemical reservoir capable of adsorbing and remobilizing pollutants. Therefore, the characterization of PTEs and trace elements in sediments can be a powerful tool to define possible anthropogenic stress in a watershed (Calmano et al. 1993; Peng et al. 2009). It is also important to highlight that trace element inputs to sediments can originate from geogenic sources (weathering, surface runoff, atmospheric deposition) and anthropic sources as agriculture and industrial and domestic discharges (Srikanth et al. 2014). In this context, the geochemistry of sediments based on quantitative, spatial, and seasonal assessment is necessary to define trace elements' role in the environment (Bouezmarni and Wollast 2005).

In tropical lakes and reservoirs, the high rainfall, temperature, and seasonal discrepancy allow high leaching rates of elements into the watershed (Fonseca et al. 2011). Specifically, in the context of the São Francisco River, the most important surface water resource regarding the domestic and industrial water supply on a national scale in Brazil, it is necessary to structure an environmental baseline to assess and monitor the anthropic evolution and their respective impacts on nature (Torres et al. 2019). In this context, the Três Marias Reservoir is the ninth-largest reservoir in Brazil, and it delimitates the segment between the Upper and Medium São Francisco River (Euclydes et al. 2001).

The construction of the reservoir in 1960 aimed to supply the economic development of the area and control overflood issues in the São Francisco River (Prado and Pompeu 2014). Currently, the Três Marias Reservoir is directly or indirectly responsible for the economic development of more than ten municipalities, highlighting Três Marias, Abaeté, and Morada Nova de Minas as the main urban centers in the region (Lima et al. 2021). Historically, the reservoir's surrounding area has been used for agriculture, tourism, forestry, housing, fish farming, waterway traffic, industry, and pastures (Euclydes et al. 2001; Horn et al. 2014; Torres et al. 2019). After changes in the regional environmental policies, the agricultural activities and the small urban activities assume the protagonist as the main pollution source in the Três Marias Reservoir (Horn et al. 2014; Lima et al. 2021).

This research aims to better comprehend the behavior of $\mathrm{Pb}, \mathrm{Cr}, \mathrm{Cu}, \mathrm{Zn}, \mathrm{Ba}, \mathrm{Ti}$, and their respective environmental context of bottom sediments geochemistry regarding the following criteria:

(1) Define a geochemical background based on the seasonal criteria, 
(2) Use different environmental indexes to propose a temporal and spatial assessment to contaminated areas, and

(3) Elucidate possibilities of pollution sources regarding the anthropogenic activities and the geological context.

\section{Material And Methods}

\subsection{Study area}

The Três Marias Hydropower Plant is inside the São Francisco River, specifically in the Upper São Francisco basin segment (Fig. 1). The Três Marias resevoir length is about $2.7 \mathrm{~km}$ and has a maximum height of $75 \mathrm{~m}$. At maximum water level, the flood zone covers $1050 \mathrm{~km}^{2}$ reaching a maximum water volume of $21 \times 10^{9} \mathrm{~m}^{3}$ (Prado and Pompeu 2014). The climate is classified as a typical tropical rainy system (Köppen - Aw), and the region experiences two different seasons: a dry winter from April to September; and rainy summer from October to March (Godinho and Godinho 2003; Prado and Pompeu 2014; Torres et al. 2016).

The regional geology describes two major stratigraphic elements that control the sediment loads in the Três Marias Reservoir: the Bambuí and the Mata da Corda Groups (Fonseca et al. 2011; Lima et al. 2021). The Bambuí Group is defined as marine paleoenvironment interlaying metapelites from Serra de Santa Helena Formation and Serra da Saudade Formation with carbonates from Sete Lagoas and Lagoa do Jacaré Formations. On the top, siliciclastic units from Três Marias Formation overlaps the metapelites-carbonates sequences (Campos and Dardenne 1997; Reis 2018). The alkaline mafic to ultramafic potassic rocks from the Mesozoic represent the Mata da Corda Formation in the area (Campos and Dardenne 1997; Fonseca et al. 2011).

Various land use and soil management were developed in the Três Marias Reservoir (Fig. 2). Since the 1990's, the natural vegetation, consisting in a transitional system between Savannah/Cerrado and Caatinga, has been replaced by the large production of housing, fishing, fruit-farms, and forestry (Baggio and Horn 2010; Horn et al. 2014; Trindade et al. 2018). The evolution of small urban centers also promotes tourism and waterway traffic in the area. The Três Marias Reservoir and its main tributaries concentrate the largest number of fishers of Minas Gerais (Alvim and Peret 2004). The left shore of the reservoir, specifically in the Indaiá and Borrachudo Rivers, also has a high potential for unconventional hydrocarbon exploration that is still in development (Lima et al. 2020). Along the shores of the reservoir, the forestry is mostly marked by the anthropogenic forest of pinus and eucalyptus (Trindade et al. 2018).

The diversity of land uses and managements, the high potential for many economic activities, and a large number of municipalities directly or indirectly connected with the reservoir make the environmental assessment a real need regarding the principles of sustainable development.

\subsection{Sampling and analytical procedures}

In two campaigns, 40 samples were collected in the dry season (July2018) and 38 in the rainy season (February2019), regarding the two main seasons mentioned previously (Fig. 1). The sampling site distribution appraised all main tributaries, and the different land uses and soil management adjacent to the Três Marias Reservoir. The sampling procedures were executed by non-metallic tools, using a composite sampling methodology on the first $15 \mathrm{~cm}$ of the bottom sediments. The sediments were cooled correctly and transported to the laboratory for further analysis.

The Nucleus of Environmental Geochemistry Research (NGqA-CPMTC/UFMG), Belo Horizonte, Brazil, performed the sediments analytical procedures. The samples were oven-dried at $303.15 \mathrm{~K}$ for 36 hours and then homogenized, pulverized, and sifted through a $0.063-\mathrm{mm}$ sieve. Fine grain-size particles were used for the chemical measuring. The 
chemical analyses were carried out following the EPA-3051A methodology, which settles the single extraction procedures using a microwave-assisted regarding the geological matrices (U.S - EPA, 1998). The samples were digested using $10 \mathrm{ml}$ of $\mathrm{HNO}_{3}$ concentrated in a microwave MARS-CEM. The inductively coupled plasma-optical emission spectrometry (ICP-OES - Spectroflame-Spectro Analytical Instruments) measured the concentration of Mg, Al, $\mathrm{Ca}, \mathrm{Cr}, \mathrm{Fe}, \mathrm{Co}, \mathrm{Cu}, \mathrm{Cd}, \mathrm{Ti}, \mathrm{Mn}, \mathrm{Ni}, \mathrm{Zn}, \mathrm{Ba}$, and $\mathrm{Pb}$ in thesediment samples. Quality assurance was given by the analysis of duplicates in $10 \%$ of the collected samples, and analytical blanks were performed for each 7-samples batch. The curves were performed against international and national laboratory standards. The Loss on Ignition (LOI) method was applied to settle the sediments' organic content (Dean 1974; Heiri et al. 2001).

\subsection{Data analysis and geochemical background}

Setting a range of concentrations expected of an ecosystem may be challenging, and it is crucial to settle a proper environmental assessment crossing different approaches. The Median \pm 2 Median Absolute deviation ( \pm 2 MAD) was applied to assess the two well-defined seasons' background values in the Três Marias Reservoir. Choosing a \pm 2 MAD method to define the threshold values creates highly conservative (low) levels for the background range, robust against outliers, and it may be more efficient for environmental proposes (Reimann and Caritat 2016). The median values were taken as representative of the background concentrations range. Variables with a high amount of data below the detection limit were excluded from the background analysis. The censored data was adopted as 0.5 times the lower detection limit (Reimann et al. 2008; Hron et al. 2010).

The Shapiro-Wilk normality test was applied to the log-transformed data to appraise the behavior of each distribution. The Mann-Whitney test (Wilcoxon test) was used to assess possible statistical differences between seasonal concentrations regarding a significance level of $95 \%(p<0.05)$. In each sampling site, the PTE concentrations were compared with the Brazilian sediment quality guidelines CONAMA 454/2012. The Brazilian legislation adopts the threshold effect level (TEL) and probable effect level (PEL) following the Canadian Sediment Quality Guidelines for the Protection of Aquatic Life (CCME, 2002). The PTE concentration was also compared with the Upper Continental Crust (UCC) levels (Wedepohl 1995).

\subsection{Environmental indexes assessment}

It was possible to settle the contemporary context of the chemical pollution in Três Marias Reservoir crossing spatial data, statistical techniques, and three different environmental indexes. Table 1 detailed the procedures and classification of each applied environmental index. The PTEs were individually appraised in each sampling site using the Geoacummulation Index (Igeo). The Pollution load index (PLI) integrated multiple elements in each sample evaluation, giving an insight into the overall pollution content in the affected areas. The concentrations of $\mathrm{Cr}, \mathrm{Cu}, \mathrm{Ba}$, $\mathrm{Ti}$, $\mathrm{Pb}$, and $\mathrm{Zn}$ were taken into account for the PLI calculus.

Table 1 Environmental indexes and their respective classification 


\begin{tabular}{|c|c|c|c|c|}
\hline Indexes & Formula & Index values & Classes & References \\
\hline \multirow{7}{*}{$\begin{array}{l}\text { Geoaccumulation } \\
\text { Index (Igeo) }\end{array}$} & \multirow{7}{*}{ Igeo $=\frac{C n}{1.5 * B n}$} & Igeo $\leq 0$ & Uncontaminated & \multirow{7}{*}{$\begin{array}{l}\text { (Loska et al. } \\
\text { 1997; Dung et } \\
\text { al. 2013) }\end{array}$} \\
\hline & & $0<$ Igeo $<1$ & $\begin{array}{l}\text { Uncontaminated } \\
\text { to moderately } \\
\text { contaminated }\end{array}$ & \\
\hline & & $1<$ Igeo $<2$ & $\begin{array}{c}\text { Moderately } \\
\text { contaminated }\end{array}$ & \\
\hline & & $2<$ Igeo $<3$ & $\begin{array}{l}\text { Moderately to } \\
\text { heavily } \\
\text { contaminated }\end{array}$ & \\
\hline & & $3<$ Igeo $<4$ & $\begin{array}{l}\text { Heavily } \\
\text { contaminated } \\
\text { Heavily }\end{array}$ & \\
\hline & & $4<$ Igeo $<5$ & $\begin{array}{l}\text { Heavily to } \\
\text { extremely } \\
\text { contaminated }\end{array}$ & \\
\hline & & Igeo $\geq 5$ & $\begin{array}{c}\text { Extremely } \\
\text { contaminated }\end{array}$ & \\
\hline \multirow{5}{*}{$\begin{array}{l}\text { Pollution Load } \\
\text { Index (PLI) }\end{array}$} & \multirow{5}{*}{$\begin{array}{c}C F=\frac{C n}{B n} \\
P L I=(C F 1 * C F 2 * \ldots * C F n)^{1 / n}\end{array}$} & $0=$ PLI & Unpolluted & \multirow{5}{*}{$\begin{array}{c}\text { (Tomlinson et } \\
\text { al. 1980) }\end{array}$} \\
\hline & & $0<\mathrm{PLI} \leq 1$ & $\begin{array}{l}\text { Baseline levels of } \\
\text { pollutant present }\end{array}$ & \\
\hline & & $1<\mathrm{PLI} \leq 10$ & Polluted & \\
\hline & & $10<\mathrm{PLI} \leq 100$ & Highly polluted & \\
\hline & & PLI $>100$ & $\begin{array}{c}\text { Progressive } \\
\text { deterioration of } \\
\text { environment }\end{array}$ & \\
\hline
\end{tabular}

$\mathrm{Cn}$ - the measured concentration at the sampling site; $\mathrm{Bn}$ - The concentration adopted as reference values;

CF - Contaminant factor.

The Igeo and PLI mapping were interpolated using Inverse Distance Weighted (IDW) through the GIS platform using QuantumGIS (QGIS®). Those indexes' spatial assessment highlights the seasonal effects in the geochemistry of bottom sediments in the reservoir. The spatial approach also enhances the probable correlation between the chemical inputs.

The box-plot analysis applied in the Igeo values using the Tukey inner fence (Tukey, 1977) for outlier evaluation brought insights about the most polluted samples. The hierarchical clustering analysis (HCA) using Ward's method as a linkage procedure considering the Euclidean distance enforced the Igeo patterns associated with contaminant inputs. The HCA was also performed for the Igeo observation data (samples) using the same methods of linkage and distance, which give some information about the clustering structure along the study area.

\section{Results And Discussion}

\subsection{Geochemical background and seasonal assessment}

The descriptive statistics and geochemical background evaluation for the dry season are summarized in Table 2. The median concentration of the elements decreased in the dry season as follows: $\mathrm{LOI}>\mathrm{Fe}>\mathrm{Al}>\mathrm{Ca}>\mathrm{Mg}>\mathrm{Mn}>\mathrm{Zn}>\mathrm{Cu}>$ $\mathrm{Ba}>\mathrm{Ti}>\mathrm{Pb}>\mathrm{Cr}$. $\mathrm{Cd}$ and $\mathrm{Ni}$ geochemical background was not appraised due to the large amount of censored data. 
Table 2

Geochemical background and thresholds for the dry season

\begin{tabular}{|c|c|c|c|c|c|c|c|c|c|c|c|}
\hline \multirow[t]{2}{*}{ Element } & \multicolumn{11}{|c|}{ Geochemical background - Dry Season } \\
\hline & $<\mathrm{DL}^{\mathrm{a}}$ & Median & Min & Max & MAD & $\begin{array}{l}\text { Upper } \\
\text { Threshold }\end{array}$ & $\begin{array}{l}\text { Lower } \\
\text { Threshold }\end{array}$ & $\begin{array}{l}\text { p- } \\
\text { LOG }^{b}\end{array}$ & $\mathrm{UCC}^{\mathrm{c}}$ & TEL $^{d}$ & PEL ${ }^{e}$ \\
\hline $\begin{array}{l}\mathrm{Fe} \\
\text { (wt\%) }\end{array}$ & 0 & 1.30 & 0.38 & 6.94 & 1.64 & 3.5 & 0.49 & 0.23 & 3.09 & - & - \\
\hline $\begin{array}{l}\text { Al } \\
\text { (wt\%) }\end{array}$ & 0 & 0.84 & 0.31 & 5.95 & 1.87 & 2.96 & 0.24 & 0.01 & 7.74 & - & - \\
\hline $\mathrm{Ca}(\%)$ & 0 & 0.36 & 0.17 & 0.85 & 1.38 & 0.67 & 0.19 & 0.39 & 29.40 & - & - \\
\hline $\begin{array}{l}\mathrm{Mg} \\
(\%)\end{array}$ & 0 & 0.22 & 0.11 & 1.23 & 1.50 & 0.49 & 0.98 & 0 & 13.51 & - & - \\
\hline $\begin{array}{l}\mathrm{Mn} \\
(\% 0)\end{array}$ & 0 & 0.091 & 0.021 & 0.284 & 2.48 & 0.53 & 0.14 & 0.33 & 0.57 & - & - \\
\hline $\begin{array}{l}\mathrm{Cr}(\mathrm{mg} \\
\mathrm{kg}-1)\end{array}$ & 0 & 16.61 & 2.01 & 83.8 & 2.52 & 104.65 & 2.58 & 0.52 & 35 & 37.3 & 90 \\
\hline $\begin{array}{l}\mathrm{Cu}(\mathrm{mg} \\
\mathrm{kg}-1)\end{array}$ & 0 & 29.6 & 7.18 & 120.2 & 1.48 & 64.58 & 13.59 & 0.24 & 14.3 & 35.7 & 197 \\
\hline $\begin{array}{l}\mathrm{Cd}(\mathrm{mg} \\
\mathrm{kg}-1)\end{array}$ & 45 & - & $\begin{array}{l}<, 12 \\
0,12\end{array}$ & $\begin{array}{l}<, 12 \\
0,1\end{array}$ & - & - & - & - & 0.102 & 0.6 & 3.5 \\
\hline $\begin{array}{l}\mathrm{Ti}(\mathrm{mg} \\
\mathrm{kg}-1)\end{array}$ & 0 & 21.4 & 7.32 & 253 & 1.89 & 74.29 & 5.81 & 0.02 & 3,12 & - & - \\
\hline $\begin{array}{l}\mathrm{Ni}(\mathrm{mg} \\
\mathrm{kg}-1)\end{array}$ & 40 & - & $\begin{array}{l}<, 595 \\
0,59\end{array}$ & 15.47 & - & - & - & - & 18.6 & 18 & 35.9 \\
\hline $\begin{array}{l}\mathrm{Zn}(\mathrm{mg} \\
\mathrm{kg}-1)\end{array}$ & 0 & 44.89 & 0.96 & 68.8 & 1.58 & 37.44 & 6.01 & 0.02 & 52.00 & 123 & 315 \\
\hline $\begin{array}{l}\mathrm{Ba}(\mathrm{mg} \\
\mathrm{kg}-1)\end{array}$ & 0 & 25.91 & 8.4 & 91 & 1.82 & 85.40 & 7.72 & 0.83 & 668.0 & - & - \\
\hline $\begin{array}{l}\mathrm{Pb}(\mathrm{mg} \\
\mathrm{kg}-1)\end{array}$ & 0 & 18.74 & 6.8 & 57.2 & 1.49 & 41.35 & 8.48 & 0.86 & 17.00 & 35 & 91.3 \\
\hline $\begin{array}{l}\text { LOI } \\
\text { (wt\%) }\end{array}$ & 0 & 6.40 & 0.46 & 15.55 & 1.49 & 14.22 & 2.88 & 0.00 & - & - & - \\
\hline \multicolumn{12}{|c|}{ a Percentage of samples below the detection limit. } \\
\hline \multicolumn{12}{|c|}{ b p-values for the Shapiro-Wilk normality test on log-transformed data. } \\
\hline \multicolumn{12}{|c|}{${ }^{\circ}$ Mean upper continental crust (Wedepohl 1995). } \\
\hline
\end{tabular}

The background values (represented by the median concentration values of each element distribution) of $\mathrm{Cu}, \mathrm{Ti}$, and $\mathrm{Pb}$ are above the mean UCC levels, whereas the values of $\mathrm{Fe}, \mathrm{Al}, \mathrm{Ca}, \mathrm{Mg}, \mathrm{Mn}, \mathrm{Cr}$, and $\mathrm{Zn}$ are under the UCC threshold. The 
maximum concentration values of $\mathrm{Cu}, \mathrm{Zn}$, and $\mathrm{Pb}$ reach the TEL guideline, while the Cr's maximum values reach the PEL guideline.

The descriptive statistics and the geochemical background appraisal for the rainy seasons are summarized in Table 3 . The median concentration of the elements decreased in the rainy season as follows: $\mathrm{LOI}>\mathrm{Fe}>\mathrm{Al}>\mathrm{Ca}>\mathrm{Mg}>\mathrm{Mn}>\mathrm{Ba}>$ $\mathrm{Cr}>\mathrm{Pb}>\mathrm{Cu}>\mathrm{Ti}>\mathrm{Zn}$. Similar to the dry season, $\mathrm{Cd}$ and Ni geochemical background values were not settled due to the large amount of censored data. 
Table 3

Geochemical background and thresholds for the rainy season

\begin{tabular}{|c|c|c|c|c|c|c|c|c|c|c|c|}
\hline \multirow[t]{2}{*}{ Element } & \multicolumn{11}{|c|}{ Geochemical background - Rainy Season } \\
\hline & $<\mathrm{DL}^{\mathrm{a}}$ & Median & Min & Max & MAD & $\begin{array}{l}\text { Upper } \\
\text { Threshold }\end{array}$ & $\begin{array}{l}\text { Lower } \\
\text { Threshold }\end{array}$ & $\begin{array}{l}\text { p- } \\
\text { LOG }^{a}\end{array}$ & $\mathrm{UCC}^{\mathrm{b}}$ & TEL $^{c}$ & $\mathrm{PEL}^{\mathrm{d}}$ \\
\hline $\begin{array}{l}\mathrm{Fe} \\
\text { (wt\%) }\end{array}$ & 0 & 3.36 & 1.84 & 7.07 & 1.39 & 6.46 & 1.75 & 0.56 & 3.09 & - & - \\
\hline $\begin{array}{l}\text { Al } \\
\text { (wt\%) }\end{array}$ & 0 & 1.70 & 0.45 & 9.52 & 1.85 & 5.81 & 0.5 & 0.84 & 7.74 & - & - \\
\hline $\mathrm{Ca}(\%)$ & 0 & 0.27 & 0.12 & 1.12 & 1.33 & 0.48 & 0.15 & 0.01 & 29.4 & - & - \\
\hline $\begin{array}{l}\mathrm{Mg} \\
(\%)\end{array}$ & 0 & 0.23 & 0.13 & 1.15 & 1.39 & 0.45 & 0.12 & 0 & 13,51 & - & - \\
\hline $\begin{array}{l}\text { Mn } \\
(\% o)\end{array}$ & 0 & 0.08 & 0.02 & 0.49 & 1.88 & 0.27 & 0.02 & 0.14 & 0.57 & - & - \\
\hline $\begin{array}{l}\mathrm{Cr}(\mathrm{mg} \\
\mathrm{kg}-1)\end{array}$ & 0 & 31.01 & 8.35 & 150.6 & 1.70 & 89.25 & 10.77 & 0.54 & 35 & 37.3 & 90 \\
\hline $\begin{array}{l}\mathrm{Cu}(\mathrm{mg} \\
\mathrm{kg}-1)\end{array}$ & 0 & 28.16 & 18.88 & 80 & 1.40 & 55.41 & 14.31 & 0.02 & 14.3 & 35.7 & 197 \\
\hline $\begin{array}{l}\mathrm{Cd}(\mathrm{mg} \\
\mathrm{kg}-1)\end{array}$ & 100 & - & $\begin{array}{l}< \\
0,74\end{array}$ & 2.06 & - & - & - & - & 0.102 & 0.6 & 3.5 \\
\hline $\begin{array}{l}\mathrm{Ti}(\mathrm{mg} \\
\mathrm{kg}-1)\end{array}$ & 0 & 20.30 & 6.08 & 250.3 & 1.79 & 64.90 & 6.35 & 0.02 & 0.75 & - & - \\
\hline $\begin{array}{l}\mathrm{Ni}(\mathrm{mg} \\
\mathrm{kg}-1)\end{array}$ & 90 & - & $\begin{array}{l}< \\
3,77\end{array}$ & 29.24 & - & - & - & - & 18.6 & 18 & 35.9 \\
\hline $\begin{array}{l}\mathrm{Zn}(\mathrm{mg} \\
\mathrm{kg}-1)\end{array}$ & 0 & 15.03 & 4.34 & 79.8 & 1.64 & 40.42 & 5.58 & 0.44 & 52 & 123 & 315 \\
\hline $\begin{array}{l}\mathrm{Ba}(\mathrm{mg} \\
\mathrm{kg}-1)\end{array}$ & 0 & 42.38 & 12.11 & 115.5 & 1.49 & 94.68 & 18.97 & 0.71 & 668 & - & - \\
\hline $\begin{array}{l}\mathrm{Pb}(\mathrm{mg} \\
\mathrm{kg}-1)\end{array}$ & 0 & 28.87 & 18.20 & 70.80 & 1.33 & 50.87 & 16.38 & 0.08 & 17 & 35 & 91.3 \\
\hline $\begin{array}{l}\text { LOI } \\
\text { (wt\%) }\end{array}$ & 0 & 6.32 & 3.99 & 16.81 & 1.52 & 14.57 & 2.74 & 0.01 & - & - & - \\
\hline \multicolumn{12}{|c|}{ a p-values for the Shapiro-Wilk normality test on logtransformed data. } \\
\hline \multicolumn{12}{|c|}{ b Mean upper continental crust (Wedepohl 1995). } \\
\hline \multicolumn{12}{|c|}{${ }^{\mathrm{c}}$ Threshold effect level for freshwater sediment guidelines based on Brazilian legislation } \\
\hline
\end{tabular}

The background values (median) of $\mathrm{Fe}, \mathrm{Cu}, \mathrm{Ti}$, and $\mathrm{Pb}$ are above the mean upper continental crust levels, while $\mathrm{Al}$, Ca, $\mathrm{Mg}, \mathrm{Mn}, \mathrm{Cr}$, and $\mathrm{Zn}$, are under the UCC threshold. 
As detailed in Table 4, Table 4, the Wilcoxon rank test denotes that $\mathrm{Fe}, \mathrm{Al}, \mathrm{Ca}, \mathrm{Cr}, \mathrm{Ba}$, and $\mathrm{Pb}$ have statistical significant differences between those two seasons, which may imply that those elements are more susceptible to seasonal physical-chemical variabilities in the reservoir. On the other hand, $\mathrm{Mg}, \mathrm{Mn}, \mathrm{Cu}, \mathrm{Ti}$, and $\mathrm{Zn}$ show no statistically significant differences between the dry and rainy season. $\mathrm{Cd}$ and Ni were removed from the Mann-Whitney test due to the large amount of censored data (Table 4).

Table 4

Wilcoxon test to assess significant statistical variability between seasons.

\begin{tabular}{|c|c|c|c|}
\hline Element & Dry Season Median & Rainy Season Median & p-value \\
\hline $\mathrm{Fe}(w t \%)$ & 1.30 & 3.36 & 0.000 \\
\hline $\mathrm{Al}(\mathrm{wt} \%)$ & 0.84 & 1.70 & 0.001 \\
\hline $\mathrm{Ca}(\%)$ & 0.36 & 0.27 & 0.000 \\
\hline $\mathrm{Mg}(\% 0)$ & 0.22 & 0.23 & 0.803 \\
\hline Mn (\%o) & 0.091 & 0.08 & 0.539 \\
\hline $\mathrm{Cr}$ (mg kg-1) & 16.61 & 31.01 & 0.000 \\
\hline Cu (mg kg-1) & 29.6 & 28.16 & 0.642 \\
\hline Ti (mg kg-1) & 21.40 & 20.30 & 0.889 \\
\hline Zn (mg kg-1) & 44.89 & 15.03 & 0.818 \\
\hline $\mathrm{Ba}$ (mg kg-1) & 25.91 & 42.38 & 0.002 \\
\hline $\mathrm{Pb}$ (mg kg-1) & 18.74 & 28.87 & 0.000 \\
\hline LOI (wt\%) & 6.40 & 6.32 & 0.345 \\
\hline
\end{tabular}

It is possible to identify areas more susceptible to adverse environmental issues comparing concentrations in each sample with the UCC, TEL, and PEL levels (Fig. 3). The Cr analysis shows that the samples from the central-left shore of the reservoir reach the TEL level (samples 9, 10, 13, 14, 22, and 23), whereas, in the rainy season, samples 17 and 20 reach the PEL threshold, pointing out a probable adverse effect on the ecosystem. The concentration above the environmental guidelines for $\mathrm{Cr}$ in samples $9-13 ; 22-23$, are spatially correlated with the agriculture and forestry zones (Fig. 2). The Brazilian legislation does not define a threshold level for Ba concentrations. It is worth noticing that $\mathrm{Ba}$ concentrations are significantly below the UCC levels in the whole reservoir in both seasons. Overall, the Pb concentrations increase in the rainy season. In both seasons, the Pb measured are above the TEL level in two different areas (samples 9-13; 22-23), highlighting warning concentrations in the Três Marias Reservoir. In addition, the Pb samples sites above the TEL levels coincide with the Cr samples sites also above the TEL concentrations, both spatially correlated with the agriculture and forestry areas.

Figure 4 correlates the measured concentrations of $\mathrm{Zn}, \mathrm{Ti}$, and $\mathrm{Cr}$, with the $\mathrm{UCC}$, TEL and PEL thresholds. It is worth emphasizing that the $\mathrm{Zn}$ ratios are under the environmental adverse effects levels and only one sample has concentrations over the UCC standard reference. The Ti concentrations are all under UCC levels, and the Brazilian legislation does not settle sediment environmental guidelines for this element. The Cu ratios are above the TEL 
threshold in two different areas (samples 9-11;39), implying a potential environmental hazard. Moreover, samples 911 have $\mathrm{Cu}, \mathrm{Cr}$, and $\mathrm{Pb}$ concentrations reaching warning levels regarding the Brazilian environmental thresholds.

The measured concentrations of each sampling station highlight zones that have alarming ratios of PTE. On the middle-left area of the reservoir, specifically in samples $9,10,13$, and 14, it is observed that $\mathrm{Cu}$ and $\mathrm{Pb}$ concentrations are above the TEL levels, while the Cr concentration reaches the PEL levels. In Fig. 2, those samples are close to the agriculture and forestry areas. The peak of $\mathrm{Ti}$ in this same area (Fig. 4b) may represent what could imply in a lithophile sign associated with a geological input in those sediments. At first insight, the association between Ti-Cr-Pb may be a consequence of the geological context of Mata da Corda formation. However, the higher concentrations of $\mathrm{Cr}$ and $\mathrm{Pb}$, and considering the presence of $\mathrm{Cu}$ also in warning levels, might represent anthropogenic inputs in the watershed of the reservoir.

The sampling sites 22 and 23 also have a similar environmental context of the samples 9-13. This area also shows concentrations over the TEL levels for $\mathrm{Cr}, \mathrm{Pb}$, and $\mathrm{Cu}$. It is worth noticing that concentrations above the sediment guidelines thresholds do not necessarily imply in polluted areas. However, proper environmental monitoring is essential to avoid further hazards to this ecosystem. The geochemical provenance assessment proposed by Lima et al. (2021) grouped all those samples in the Mata da Corda Formation influencing area, which means that the potassic ultramafic rocks could naturally enhance the $\mathrm{Cr}$ and $\mathrm{Pb}$ concentration in those samples. The higher concentrations of $\mathrm{Ti}$ in those samples complement the hypothesis of a geogenic contribution of PTE. In spite of that, Fig. 2 also shows these samples spatially correlated with forestry and agriculture zones, which could imply an additional anthropogenic input in those places, explaining the high concentrations of $\mathrm{Cu}$ above the TEL thresholds. The surrounding land uses and management might also increase the surface runoff in those locations. Therefore, the $\mathrm{Cu}, \mathrm{Cr}$, and $\mathrm{Pb}$ levels in the middle-east of the reservoir may be affected by a geogenic input naturally enhanced with $\mathrm{Cr}, \mathrm{Pb}$, and $\mathrm{Ti}$, and, concomitantly, by an anthropogenic input explaining the high $\mathrm{Cr}$ levels and a probable increment of $\mathrm{Cu}$ and $\mathrm{Pb}$ concentrations. In addition, an environmental environmental assessment based on the Geoaccumulation indexPollution load index may enhance this hypothesis.

The dry season specifically shows Cu concentration levels above the TEL threshold in sample 39. In the same sampling site, it is worth highlighting the Zn concentrations above the UCC levels and significantly higher than the overall concentrations of the reservoir.

Nonetheless, the rainy season does not have the same environmental-chemical behavior. The Mann-Whitney test shows no statistical differences between seasons, enhancing the possibility of punctual pollution sources at this sampling site. The season's rainfall could also act on the reservoir as a purification (dilution) process, explaining this difference between seasons. The environmental index assessment was applied to effectively identify the anthropogenic affected zones and understand other anthropogenic stressed areas.

\subsection{Geoaccumulation index assessment (Igeo)}

The Igeo index was used as a reference for estimating the pollution content in both seasons in the reservoir (Table 5). The mean Igeo evaluation for $\mathrm{Cr}, \mathrm{Cu}, \mathrm{Ti}, \mathrm{Zn}, \mathrm{Ba}$, and $\mathrm{Pb}$ for both seasons indicates an overall unpolluted ecosystem (Igeo $\leq 0)$; however, some sampling stations have a sign of contamination. All Igeo(Ba) and Igeo(Pb) denoted an uncontaminated reservoir for both seasons. Igeo( $\mathrm{Cr})$ and $\operatorname{lgeo}(\mathrm{Zn})$ values indicate unpolluted to moderately polluted environments in specific sites for both seasons. The Igeo(Ti) reaches the unpolluted to moderately polluted system in the dry season and moderate pollution in the rainy season. The Igeo $(\mathrm{Cu})$ indicates an unpolluted to moderately polluted system in the dry season and unpolluted in the rainy season. 
Table 5

Geoacumulation index and percentage enrichment factor descriptive summary

\begin{tabular}{|lllllll|}
\hline Elements & \multicolumn{2}{l}{ Dry season } & \multicolumn{5}{c|}{ Rainy season } \\
\cline { 2 - 7 } & Mean Igeo & Igeo min & Igeo max & Mean Igeo & Igeo min & Igeo max \\
\hline $\mathrm{Ba}$ & -0.82 & -2.51 & 0.93 & -0.70 & -2.40 & 0.86 \\
\hline $\mathrm{Cr}$ & -1.19 & -4.10 & 1.28 & -0.87 & -2.95 & 1.22 \\
\hline $\mathrm{Cu}$ & -0.78 & -2.88 & 1.18 & -0.66 & -1.31 & 0.78 \\
\hline $\mathrm{Pb}$ & -0.75 & -2.26 & 0.81 & -0.67 & -1.50 & 0.46 \\
\hline $\mathrm{Ti}$ & -1.20 & -3.08 & 1.48 & -1.26 & -3.44 & 1.92 \\
\hline $\mathrm{Zn}$ & -0.98 & -4.89 & 1.27 & -0.83 & -2.61 & 1.59 \\
\hline
\end{tabular}

Figure 5 elucidates the boxplot distribution of Igeo index in each season. This analysis intends to highlight possible anomalies in the Igeo distribution in the reservoir. $\lg \mathrm{eo}(\mathrm{Pb})$ and $\operatorname{lgeo}(\mathrm{Ba})$ values do not show pollution in both seasons. Igeo(Cu) values denote an unpolluted environment in the rainy season, while two samples highlighted as outliers in the dry season are classified as moderately contaminated. The statistical seasonal differences and the lgeo assessment highlight the possibility of a mechanism that concentrates $\mathrm{Cu}$ in the sediments in the dry season or rainfall acts as a dilution factor in the rainy season. The positive outliers in the Igeo(Zn) indicate a differential behavior of the $\mathrm{Zn}$ distribution in the reservoir in both seasons. The Igeo(Cr) reaches the uncontaminated to moderately contaminated classification; however, no outliers appear in the distribution. The Igeo(Ti) displays the highest Igeo values in the reservoir and one outlier in the dry season earns the moderately contaminated classification.

Figure 6 shows a hierarchical clustering analysis regarding the Igeo values in each season. In both seasons, two clusters grouping Igeo(Pb)-Igeo( $(\mathrm{Cr})$-Igeo( $\mathrm{Ti}$ ) and Igeo(Ba)-Igeo(Cu)-Igeo( $\mathrm{Zn}$ ) were defined. This result may support the hypothesis of the geogenic inputs of $\mathrm{Pb}, \mathrm{Cr}$ and $\mathrm{Ti}$, which are related to the lithotypes from Mata da Corda Group, as mentioned in Sect. 3.1. On the other hand, Zn, Cu and Ba should have their provenance from both geogenic (Bambuí Group; Lima et al. 2021) and anthropogenic sources. This interpretation is better understood in the Igeo distribution maps in the Três Marias Reservoir.

Figure 7 assesses the Igeo(Cr), Igeo(Ti), and Igeo(Pb) distribution, while Fig. 8 assesses the Igeo distribution of $\mathrm{Zn}$, Ba, and $\mathrm{Cu}$ distribution maps. The Igeo( $\mathrm{Pb})$ assessment shows unpolluted to moderately polluted in a central-south area of the reservoir in both seasons, with slight decreasing index values during the rainy season. The $\mathrm{Pb}$ concentrations are also above the TEL levels in these polluted areas. The Igeo( $\mathrm{Cr}$ ) distribution has significantly changed between the seasons, as exposed in Fig. 7a and Fig. 7b. It is worth noticing that the Wilcoxon-test (Table 4) and the Cr concentration in each sample (Fig. 3a) also highlight the seasonal differences in the $\mathrm{Cr}$ distribution. The Cr-polluted areas on the east shore of the reservoir are mainly spatially correlated with agriculture/forestry, as shows in the land use map (Fig. 2). The rainy season shows high Cr-pollution signs in the reservoir's east margin. When those concentrations are compared with the Brazilian sediments guidelines (Fig. 3a and Fig. 3c), the $\mathrm{Cr}$ and Pb levels reach the environmental thresholds (TEL and PEL), standing an alarm about possible adverse concerns in those areas. The moderate pollution at the Indaiá River appears only in the rainy season, implying a punctual contamination source high influenced by seasonality. The Igeo(Ti) distribution is quite similar in both seasons, showing its higher values in the reservoir's central zone. 
The similarities between the Ti-Cr-Pb behaviors enhance a geogenic input hypothesis correlated to ultramafic rocks from the Mata da Corda formation. The hierarchical clustering analysis in the Igeo values (Fig. 6) reinforces this geochemical assemblage geogenic-related. Although, the higher Igeo values of $\mathrm{Cr}$ and $\mathrm{Pb}$ near the agriculture zones highlight the possibility of anthropogenic inputs towards the sediment strata in the reservoir. Another concern is the $\mathrm{Cr}$ and $\mathrm{Pb}$ concentrations above the TEL and PEL thresholds, implying the need for proper environmental monitoring to avoid adverse biota impacts.

Figure 8 shows analog distributions between the Igeo(Zn)- Igeo(Ba)- Igeo(Cu) values. The Igeo(Zn) distribution in both seasons is comparable, with a slight increase in the rainy season. The Wilcoxon-test also shows no statistical seasonal differences in the Zn distribution. The Igeo (Zn) mapping (Fig. 8a and Fig. 8b) denotes moderately pollution spatially correlated with the forestry zones (Fig. 2). It is worth noticing that in any sample, the $\mathrm{Zn}$ concentrations surpass the environmental guidelines thresholds. The Igeo(Ba) indicate unpolluted to moderately polluted at the reservoir's west shore in both seasons. The Igeo $(\mathrm{Cu})$ reaches a moderate level of pollution in the dry season and unpolluted to moderately polluted in the rainy season. The slight decrease of the lgeo( $\mathrm{Cu})$ in the rainy season may be an effect of the intense rainfall in the reservoir. However, the Wilcoxon-test does not show statistical differences in Cu levels between seasons. The Cu-polluted areas are spatially correlated with forestry and agriculture (Fig. 2), and the Cu concentrations are above the TEL level in samples 9 to 12 (Fig. 4c).

It is worth noticing the spatial similarities between the $\operatorname{lgeo}(\mathrm{Zn}), \operatorname{lgeo}(\mathrm{Cu})$, and $\operatorname{lgeo}(\mathrm{Ba})$ distribution also accordingly with the hierarchical cluster analysis. In the Três Marias Reservoir, the multi-element geochemical mapping associates Zn-Cu-Ba with the Bambuí Group (Lima et al. 2021). Therefore the similarities between Zn-Cu-Ba may be geogeniccorrelated. It is also important to notice that $\mathrm{Cu}, \mathrm{Cr}$, and $\mathrm{Pb}$ distribution are spatially correlated with the forestry and agriculture zones, both above the TEL levels and probably connected with anthropogenic inputs accordingly to the Igeo classification.

\subsection{Pollution Load Index (PLI) assessment and hierarchical cluster analysis (HCA) considering the observation data (samples)}

The Pollution Load Index (PLI) was applied to summarize the Igeo assessment and delimitate probable susceptible areas in the Três Marias Reservoir. The PLI values in the dry season range from 0.25 to 2.28, whereas the PLI values in the rainy season ranges from 0.56 to 2.11 . In both seasons, the PLI index (Table 1) classifies the reservoir predominantly as unpolluted to a baseline level of pollutants environment. However, in specific sites, the PLI indicates a sign of pollution. The PLI mapping (Fig. 9) provides an overall pollution rate in the reservoir, considering all the mutually appraised elements.

The pollution load index sectorized the reservoir in different anthropic stressed areas. The middle-south of the reservoir shows the higher levels of the PLI in both seasons. In those areas, the Igeo index assessment shows pollution signs of $\mathrm{Cr}, \mathrm{Cu}, \mathrm{Zn}$, and $\mathrm{Pb}$. The west shore of this zone was influenced by forestry, whereas the east shore was affected by agriculture. In this zone, the $\mathrm{Cr}, \mathrm{Cu}$, and $\mathrm{Pb}$ reach the TEL threshold, indicating the possibility of adverse environmental effects on nature. The similar behavior of $\mathrm{Cr}-\mathrm{Pb}-\mathrm{Ti}$ and the hierarchical clustering analysis highlight a correlated geogenic input from the Mata da Corda Group that could increase their concentration. However, the Igeo spatial assessment also shows signs of anthropogenic stress in that region, where the lgeo(Zn) might be an indicator of anthropogenic input. Those elements may be associated with the use of pesticides in agriculture and forestry that could increase the PTE concentrations on sediments. Another hypothesis is that the marginal land use and management may intensify the runoff surface on the shores, raising the PTE concentration to warning levels (above the TEL threshold). In this case, the environmental indexes indicate a polluted zone, and the PTE ratios are higher than the sediment quality guidelines, implying a susceptible area for ecological issues.

Page $12 / 26$ 
The Indaiá River, on the western portion of the reservoir, shows higher PLI levels during the rainy season (samples 17 and 20). The Igeo(Cr) assessment classified this zone as moderately polluted, and the $\mathrm{Cr}$ measured concentrations reaches the PEL reference value, indicating a probable adverse effect to the environment. Regardless, this evaluation does not apply to the dry season, enhancing the hypothesis of a pollution source highly affected by seasonality. Grassland and pastures predominantly occupy the Indaiá River's downstream, which could not explain the Cr seasonal behavior in this area. The geological context also does not justify an intense $\mathrm{Cr}$ input in this site. The high concentration of $\mathrm{Cr}$ in this area could be connected with the role of pisciculture that is strongly affected by the seasonality, once the Indaiá River has one of the largest Tilapia fish-farming of Brazil.

The PLI reaches values slightly higher than 1 in the extreme north of the Três Marias Reservoir for both seasons. This area has Zn concentrations higher than the UCC levels, and the Cu concentrations reach the TEL reference value. The Igeo evaluation shows slight pollution of $\mathrm{Zn}$ and $\mathrm{Cu}$ in those sites, which could be explained by the heavy waterway traffic in this zone; however, it would be necessary a local assessment for better understanding.

For a better comprehension of Igeo values distribution in the study area, the HCA considering the observation data (samples) was applied using Igeo values for $\mathrm{Zn}, \mathrm{Ba}, \mathrm{Cu}, \mathrm{Cr}, \mathrm{Ti}$, and $\mathrm{Pb}$ in each season. Figure $10 \mathrm{~A}$ and Fig. 10B show the cluster observation results, identifying three different groups for each season. Figure 10C and Fig. 10D identify the obtained clusters on the map, correlating the results with the PLI mapping from Fig. 9.

In both seasons, the cluster 1 and 2 (the blue and green circles in the maps, respectively) grouped more samples in upstream and downstream, respectively. It may reflect a differential geochemistry signature in the sediment's structure between those two zones, either by geological features or anthropogenic activities in those regions. However, cluster 3 (yellow circles) separates samples with distinctive Igeo associations, highlighting probable polluted areas. The spatial evaluation of cluster 3 has a strong correlation with high PLI values, enhancing the hypothesis of probably affected areas for both seasons.

\section{Conclusion}

The median \pm 2 MAD defined a regional background based on the seasonal criteria. These new standard values allowed a proper environmental evaluation of the sediments' actual geochemical settings from the Três Marias Reservoir. Comparing the measured concentration in each sample with the Brazilian sediment quality guidelines brought insights into areas prone to adverse environmental issues. The hierarchical clustering analysis of the Igeo classes denoted a geochemical association similar to the geogenic inputs from the reservoir's geological structures. However, the Igeo classification indicates some polluted areas related to anthropogenic influences. The Igeo index mapping allowed the spatial identification of probable anthropogenic stressed zones and different behaviors between two seasons. The PLI assessment summarized the role of the PTEs in the Três Marias Reservoir, indicating three more susceptible zones that should be better managed. The middle-south of the reservoir shows signs of agriculture and forestry influences on the bottom sediments' quality. The Igeo and PLI index assessment highlights the hypothesis about how the anthropic impacts could be affecting the sediments leading to warning concentrations (above the TEL and PEL standards), enhancing the need for an evaluation to comprehend the role of PTE on this site. The environmental indexes mapping also indicated a $\mathrm{Cr}$ pollution source highly associated with the seasonality behavior. A third probable affected zone is located in the extreme north of the reservoir regarding the Cu levels higher than the TEL reference value and the PLI slightly higher than 1. The HCA applied to the observation data (samples) was a multivariate technique based on the Igeo values used to validate the PLI index interpretation.

These results provide an environmental assessment of a sensible area for Brazilian sustainable development on a national scale. The geochemical background regarding the seasonal criteria contributes as a powerful tool for further 
environmental assessment and management. The highlighted anthropic pressures using the environmental indexes furnished the most susceptible zones in the ecosystem. Further studies should be appraised to understand the real magnitude of the contamination issues. The results can enforce environmental policymaking and create a baseline for new strategies to improve the water resources quality in the Upper São Francisco River Basin.

\section{Declarations}

\section{- Ethics approval and consent to participate}

Not applicable

\section{- Consent for publication}

Not applicable

\section{- Availability of data and materials}

The datasets generated and analysed during the current study are available in the [Universidade Federal de Minas Gerais] repository [http://hdl.handle.net/1843/33552] - (Master degree of the corresponding author).

\section{- Competing interests}

The authors declare that they have no known competing financial interests or personal relationships that could have appeared to influence the work reported in this paper.

\section{- Funding}

The Higher Education Personnel Improvement Coordination (Coordenação de Aperfeiçoamento de Pessoal de Nível Superior - Brasil, CAPES) financed the authors in this research.

\section{- Authors' contributions}

GFCL contributions: Field work (sampling); Laboratorial analysis (execution of the sediments' extraction); Writing; Discussion of the results and conclusions.

CCB contributions: Field work (sampling); Writing; Discussion of the results;

AHHC contributions: Coordinate the laboratorial analysis (which method we should apply; how to measure it; quality assurance and control procedures); Discussion about the results and conclusions;

EDM contributions: Help to define which environmental index we should applied and how the best way for mapping it; Discussion about the best statistical approach to use in this research; Discussion about the results.

HBF contributions: Field work (definition of sampling sites); Discussion about the results.

\section{- Acknowledgement}

The authors sincerely thank the Coordination of Superior Level Staff Improvement for their support (CAPES); the Center of Environmental Geochemistry (NGqA/CPMTC-Federal University of Minas Gerais) for their laboratory assistance; the Geosciences Institute of Federal University of Minas Gerais (IGC-UFMG) for their academic assistance; and the Chico Mendes Institute for Biodiversity Conservation (ICMBio) for the logistic support in this research. 


\section{References}

1. Alvim MC, Peret AC (2004) Food resources sustaining the fish fauna in a section of the upper São Francisco River in Três Marias, MG, Brazil. Brazilian J Biol 64:195-202. https://doi.org/10.1590/S1519-69842004000200003

2. Baggio H, Horn AH (2010) Teores totais e distribuição dos metais pesados $\mathrm{Cu}, \mathrm{Cd}, \mathrm{Cr}$, $\mathrm{Ni}$, Pb e Zn nos sedimentos de corrente e fundo do rio Formoso - MG. Geografias 06:107-117

3. Bouezmarni M, Wollast R (2005) Geochemical composition of sediments in the Scheldt estuary with emphasis on trace metals. Hydrobiologia 540:155-168. https://doi.org/10.1007/s10750-004-7131-x

4. Calmano W, Hong J, Förstner U (1993) Binding and mobilization of heavy metals in contaminated sediments affected by $\mathrm{pH}$ and redox potential. Water Sci Technol 28:223-235

5. Campos JEG, Dardenne MA (1997) Estratigrafia E Sedimentação Da Bacia Sanfranciscana: Uma Revisão. Rev Bras Geociências 27:269-282. https://doi.org/10.25249/0375-7536.1997269282

6. Dean WE (1974) Determination of carbonate and organic matter in calcareous sediments and sedimentary rocks by loss on ignition: comparison with other methods. J Sediment Petrol 44:242-248

7. Dung TTT, Cappuyns V, Swennen R, Phung NK (2013) From geochemical background determination to pollution assessment of heavy metals in sediments and soils. Rev Environ Sci Biotechnol 12:335-353. https://doi.org/10.1007/s11157-013-9315-1

8. Euclydes HP, Ferreira PA, Rubert OAV, dos Santos RM (2001) Regionalização Hidrológica na Bacia do Alto São Francisco a Montante da Barragem de Três Marias, Minas Gerais. RBRH - Rev Bras Recur Hídricos 6:81-105

9. Fonseca R, Patinha C, Barriga F, Morais M (2011) Geochemistry of metals in the bottom sediments of tropical dam reservoirs in San Francisco River (Três Marias, MG) and Tocantins River (Tucuruí, PA), Brazil Rita Fonseca 1; Carla Patinha 2; Fernando Barriga 3; Manuela Morais 4. In: International Water Association (ed) Proceedings of Specialized Conference on Watershed \& River Basin Management. Recife, p 8

10. Godinho HP, Godinho AL (2003) Águas, peixes e pescadores do São Francisco das Minas Gerais. Editora PUCMINAS, Belo Horizonte

11. Heiri O, Lotter AF, Lemcke G (2001) Loss on ignition as a method for estimating organic and carbonate content in sediments: reproducibility and comparability of results. J Paleolimnol 25:101-110

12. Horn AH, Baggio H, Schimith R (2014) Selected element distribution in bottom sediment samples from Três Marias lake and its significance, Minas Gerais, Brazil. Rom J Miner Depos 87:39-42

13. Hron K, Templ M, Filzmoser P (2010) Imputation of missing values for compositional data using classical and robust methods. Comput Stat Data Anal 54:3095-3107. https://doi.org/10.1016/j.csda.2009.11.023

14. Lima GFC, Bento CC, Horn AH, et al (2021) Geochemical signature and environmental background of bottom sediments in a tropical aquatic system: the Três Marias Reservoir , Brazil. Environ Monit Assess 193:1-15

15. Lima J da SD, Ferreira VG, Duarte J de CM, et al (2020) PROJETO GASBRAS: PROPOSTA METODOLÓGICA PARA LEVANTAMENTO DE BASELINE E ANÁLISES DE VIABILIDADE DA PRODUÇÃO DE GÁS NÃO CONVENCIONAL EM UMA ÁREA DE INVESTIGAÇÃO NA BACIA DO SÃO FRANCISCO - MINAS GERAIS. In: III Simpósio da Bacia Hidrográfica do Rio São Francisco. Belo Horizonte, pp 1-8

16. Loska K, Cebula J, Pelczar J, et al (1997) Use of enrichment, and contamination factors together with geoaccumulation indexes to evaluate the content of $\mathrm{Cd}, \mathrm{Cu}$, and $\mathrm{Ni}$ in the Rybnik water reservoir in Poland. Water, Air Soil Pollut 93:347-365 
17. Peng J, Song Y, Yuan P, et al (2009) The remediation of heavy metals contaminated sediment. J Hazard Mater 161:633-640. https://doi.org/10.1016/j.jhazmat.2008.04.061

18. Prado IG, Pompeu PS (2014) Vertical and seasonal distribution of fish in Três Marias reservoir. Lake Reserv Manag 30:393-404. https://doi.org/10.1080/10402381.2014.955221

19. Reimann C, Caritat P De (2016) Establishing geochemical background variation and threshold values for 59 elements in Australian surface soil. Sci Total Environ. https://doi.org/10.1016/j.scitotenv.2016.11.010

20. Reimann C, Filzmoser P, Garrett R, Rudolf D (2008) Statistical Data Analysis Explained: Applied Environmental Statistics with R. John Wiley \& Sons Ltd, England

21. Reis HLS (2018) Gás natural. In: Pedrosa-Soares AC, Voll E, Cunha EC (eds) Recursos minerais de Minas Gerais. Companhia de Desenvolvimento de Minas Gerais (CODEMGE), Belo Horizonte, pp 1-39

22. Srikanth K, Ahmad I, Rao JV (2014) Seasonal trend of potential toxic elements in seawater and sediments from Tuticorin coast. Water Air Soil Pollut 225:. https://doi.org/10.1007/s11270-014-2069-8

23. Tomlinson DL, Wilson JG, Harris CR, Jeffrey DW (1980) Problems in the assessment of heavy-metal levels in estuaries and the formation of a pollution index. Helgoländer Meeresuntersuchungen 33:566-575. https://doi.org/10.1007/BF02414780

24. Torres I, Horn A, Lemos R (2019) Metal dynamics in a tropical watershed: The São Francisco river and its compartments. Geochim Bras 33:221-233. https://doi.org/10.21715/gb2358-2812.2019332221

25. Torres IC, Ribeiro EV, Trindade WM, et al (2016) Relationship Between Metal Water Concentration and Anthropogenic Pressures in a Tropical Watershed, Brazil. Geochim Bras 30:158-172. https://doi.org/10.21715/GB2358-2812.2016302158

26. Trindade WM, Horn AH, Aranha PRA, et al (2018) Evironmental evaluation of the middle São Francisco River basin between Três Marias and Pirapora , using chemical and geophysical investigation in sediment profiles from selected marginal lagoons. Geochim Bras 32:79-87. https://doi.org/10.21715/GB2358-2812.2018321079

27. Wedepohl KH (1995) The composition of the continental crust. Geochim Cosmochim Acta 59:1217-1232

\section{Figures}




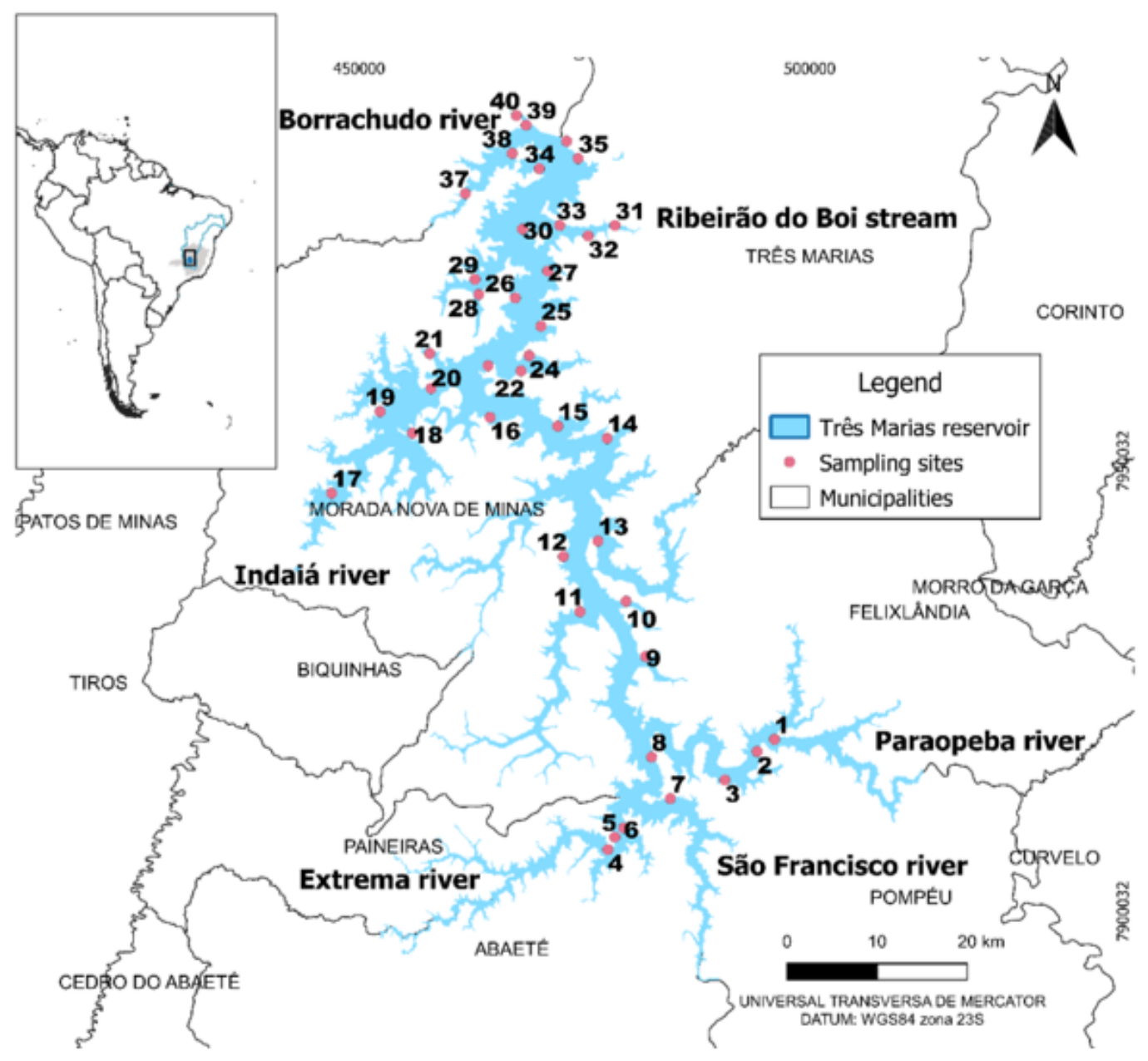

Figure 1

Location and sampling sites in the Três Marias Reservoir. 


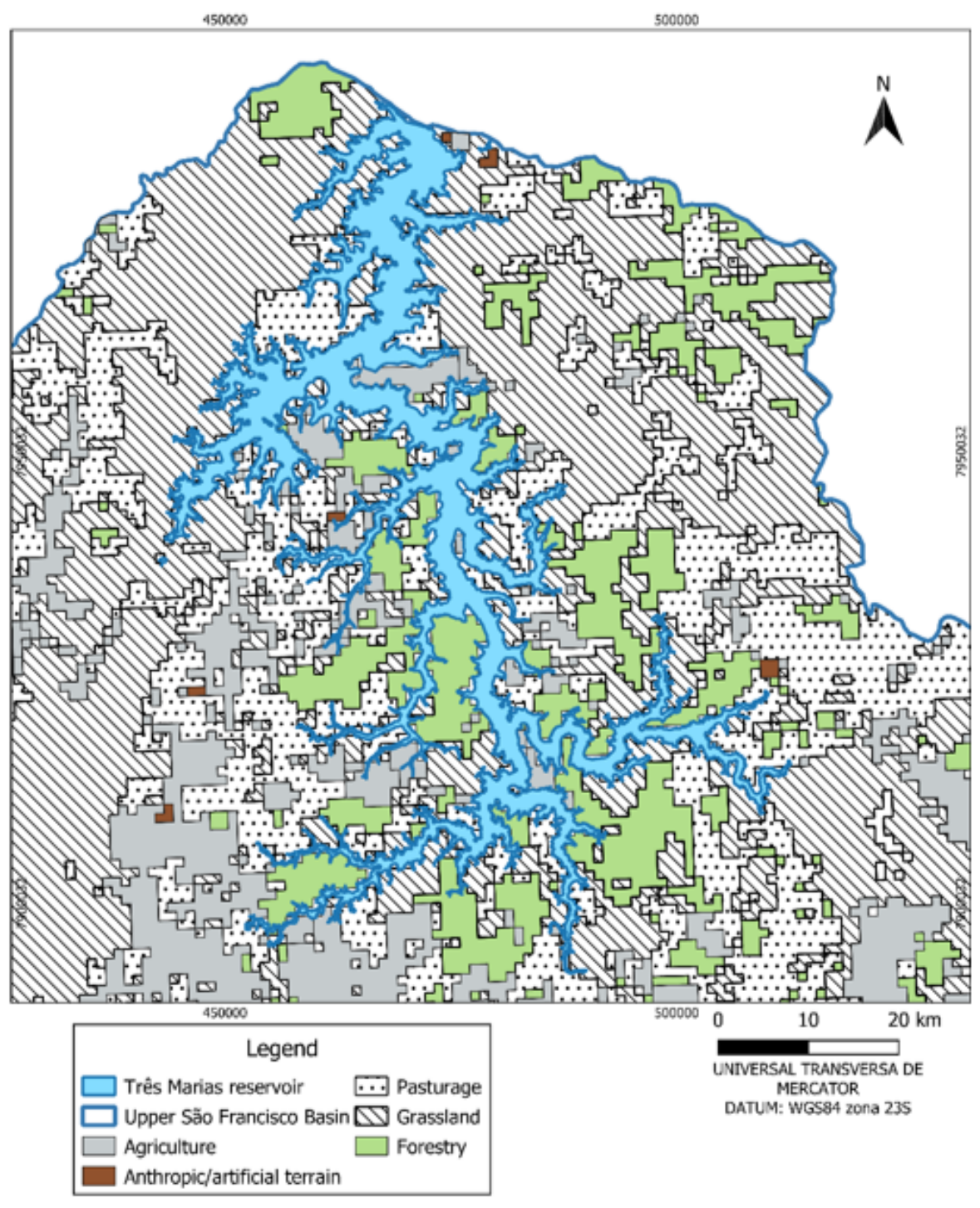

Figure 2

Land use and soil management of the Três Marias Reservoir. 

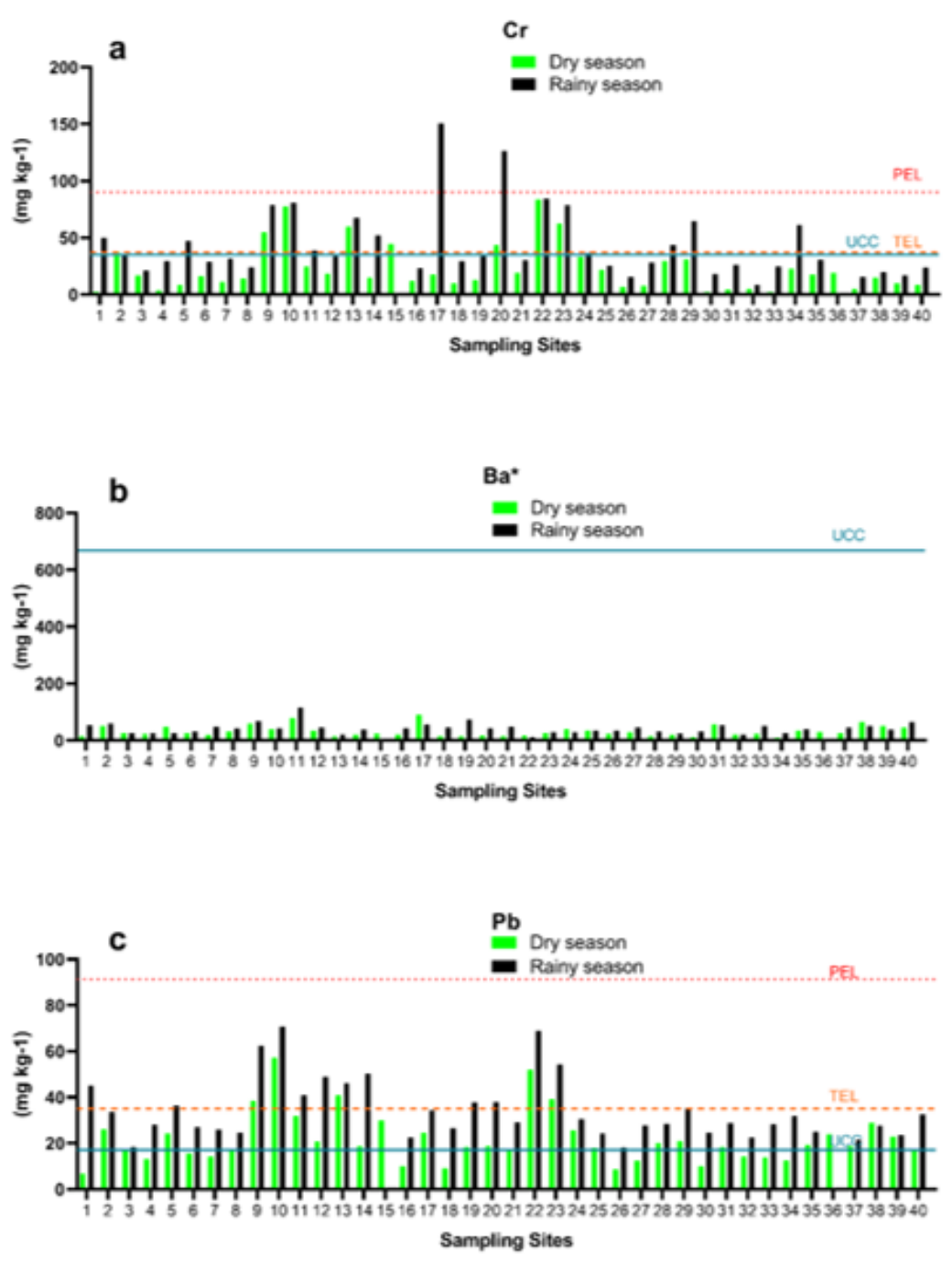

Figure 3

Trace elements measured in the Três Marias Reservoir in the dry season (green bars) and the rainy season (black bars).

(a) Cr concentrations in both seasons; (b) Ba concentrations in both seasons; (c) Pb concentrations in both seasons; UCC - Mean upper continental crust (Wedepohl 1995); TEL - Threshold effect levels; PEL - Probable effect levels; *The Brazilian legislation do not define TEL and PEL thresholds for $\mathrm{Ba}$. 

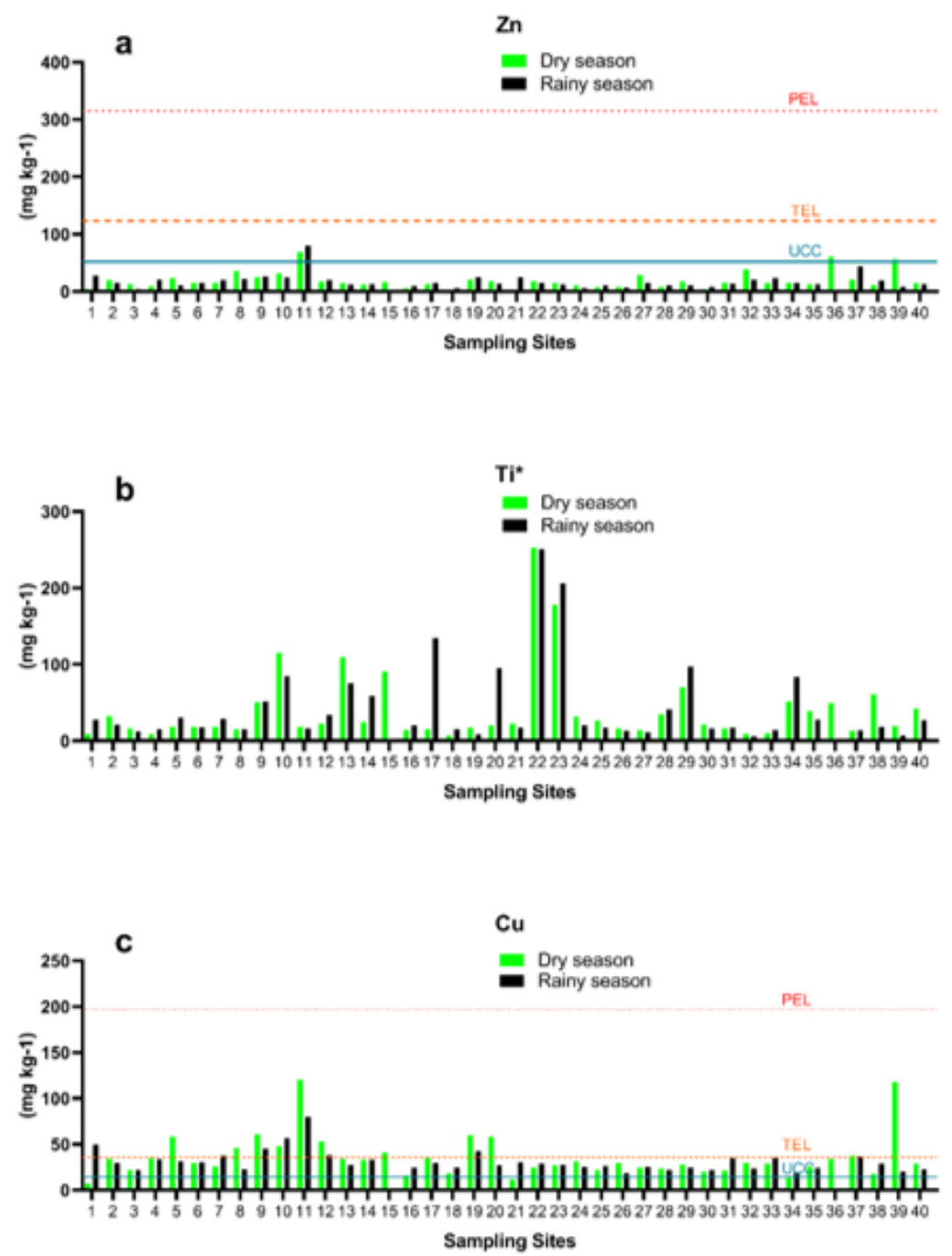

\section{Figure 4}

Trace elements measured in the Três Marias Reservoir in the dry season (green bars) and the rainy season (black bars). (a) Zn concentrations in both seasons; (b) Ti concentrations in both seasons; (c) Cu concentrations in both seasons; UCC - Mean upper continental crust (Wedepohl 1995); TEL - Threshold effect levels; PEL - Probable effect levels; *The Brazilian legislation do not define TEL and PEL thresholds for Ti while the UCC limit is significantly above the scale of the graph. 


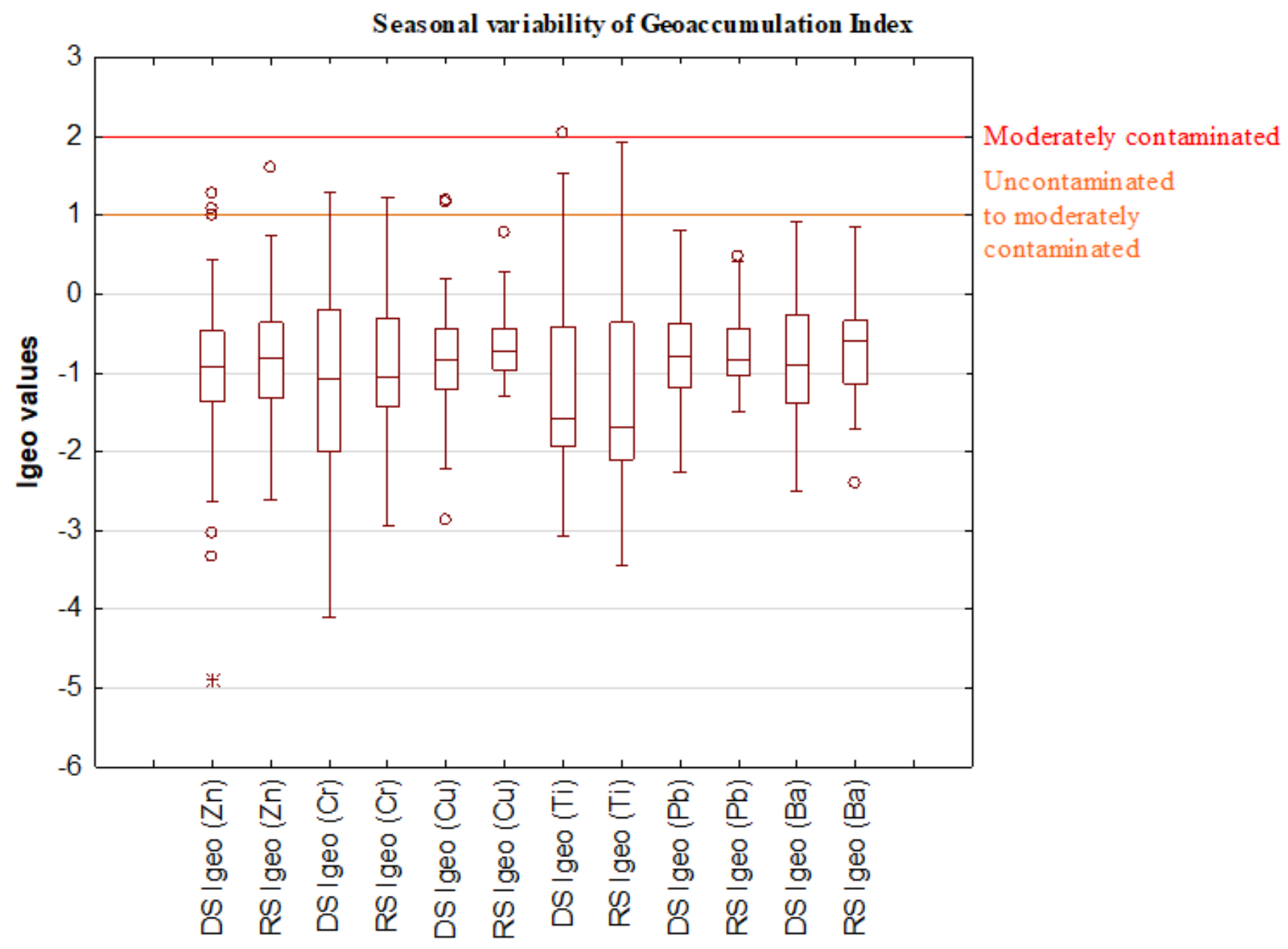

Figure 5

Box-plot with Igeo index of each season. DS Igeo - Dry season; RS Igeo - Rainy season. 

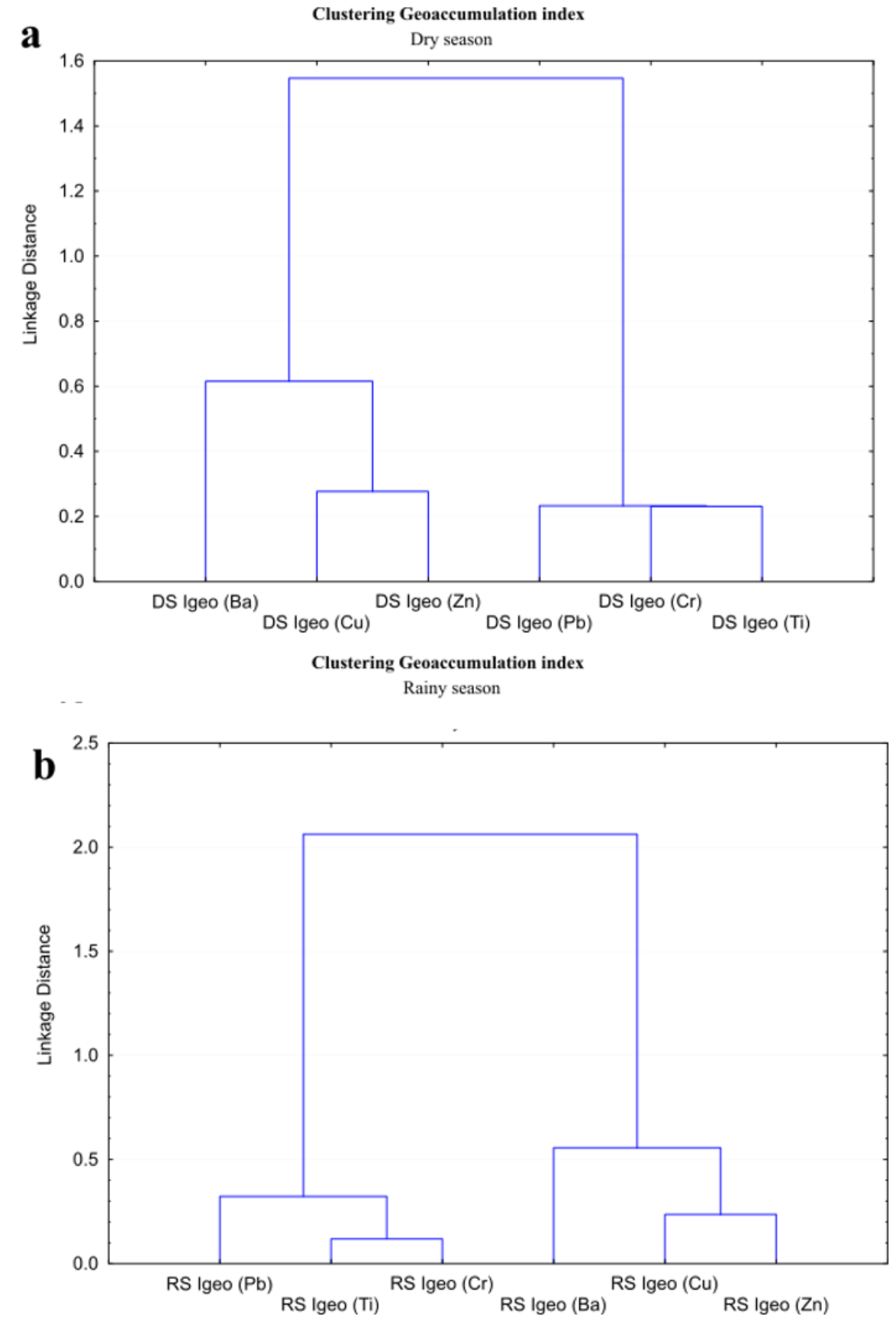

Figure 6

Hierarchical clustering analysis of the Geoaccumulation Index in both seasons. DS Igeo - Dry season; RS Igeo - Rainy season. (a) - HCA of the dry season; (b) HCA of the rainy season. 


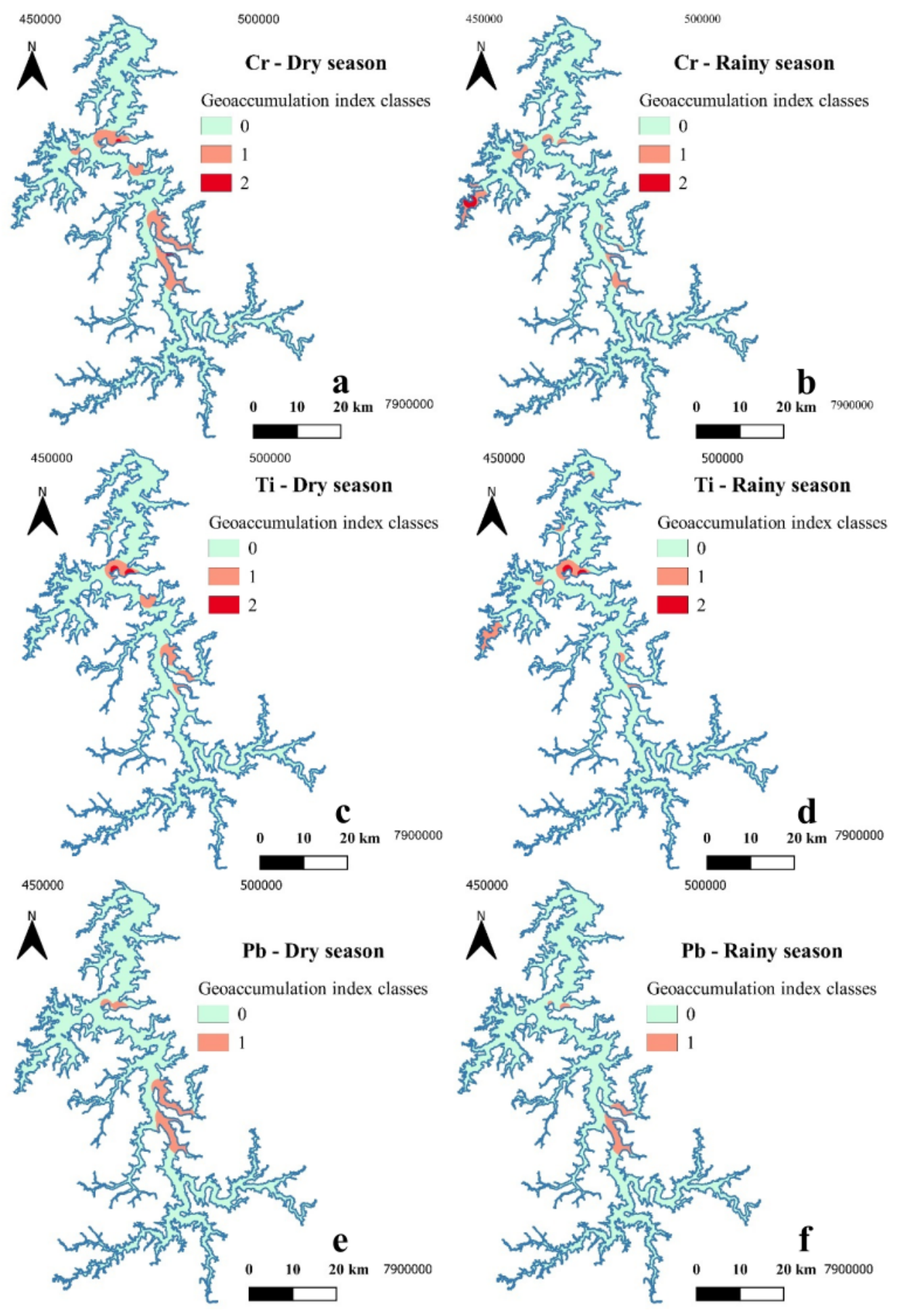

Figure 7

Geoacummulation classes were mapping for $\mathrm{Cr}$, $\mathrm{Ti}$, and $\mathrm{Pb}$. Igeo Classes: 0 - Unpolluted; 1 - Unpolluted to moderately polluted; 2 - Moderately polluted. (a) - Igeo(Cr) in the dry season; (b) - Igeo(Cr) in the rainy season; (c) - Igeo(Ti) in the dry season; (d) - Igeo(Ti) in the rainy season; (e) - Igeo(Pb) in the dry season; $(f)$ - $\operatorname{lgeo}(\mathrm{Pb})$ in the rainy season; 


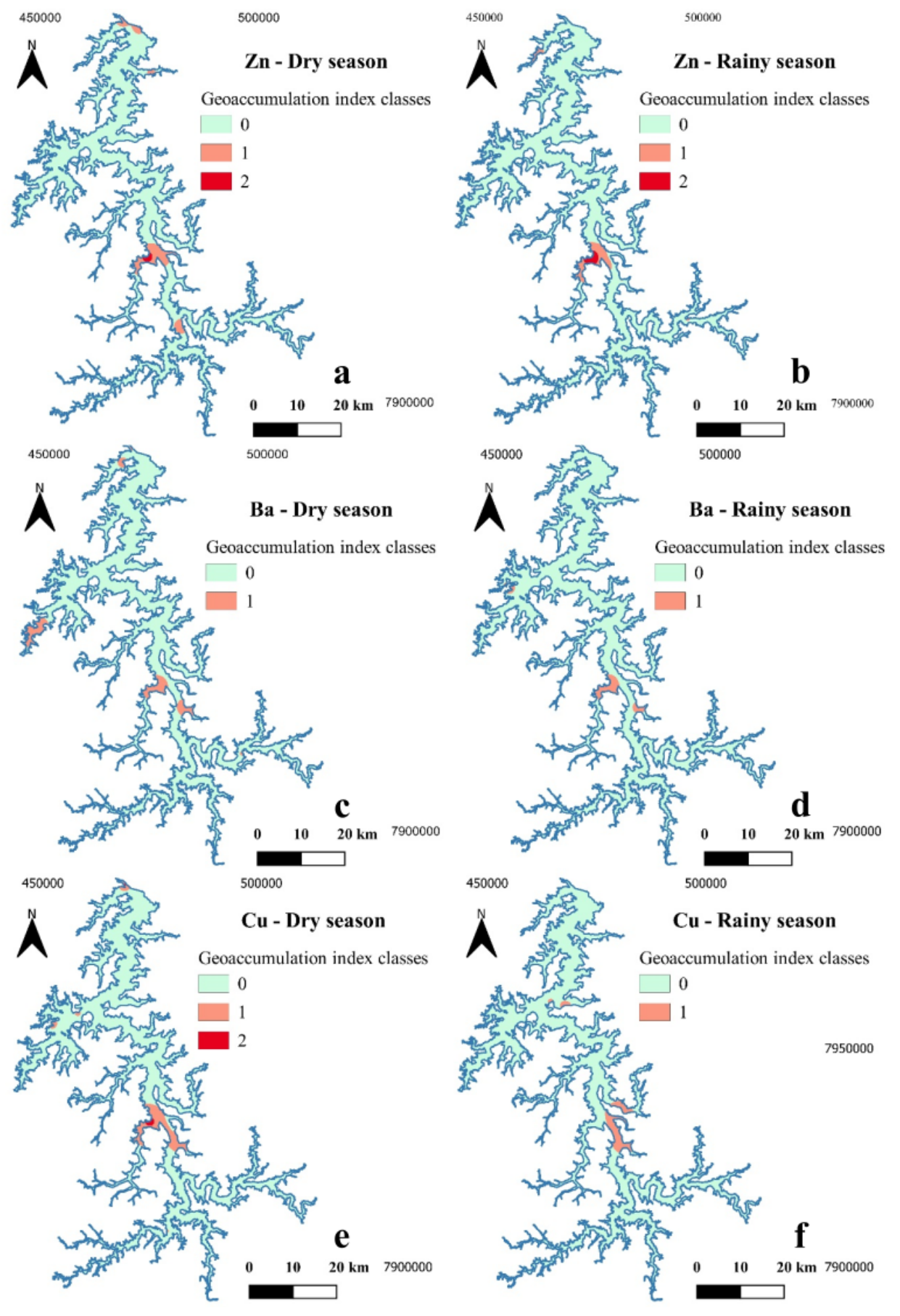

Figure 8

Geoacummulation classes were mapping for $\mathrm{Zn}, \mathrm{Ti}$, and $\mathrm{Cu}$. Igeo Classes: 0 -Unpolluted; 1 - Unpolluted to moderately polluted; 2 - Moderately polluted. (a) - Igeo(Zn) - in the dry season; (b) - Igeo(Zn) in the rainy season; (c) - Igeo(Ba) in the dry season; (d) - Igeo(Ba) in the rainy season; (e) - Igeo(Cu) in the dry season; (f) - Igeo(Cu) in the rainy season; 

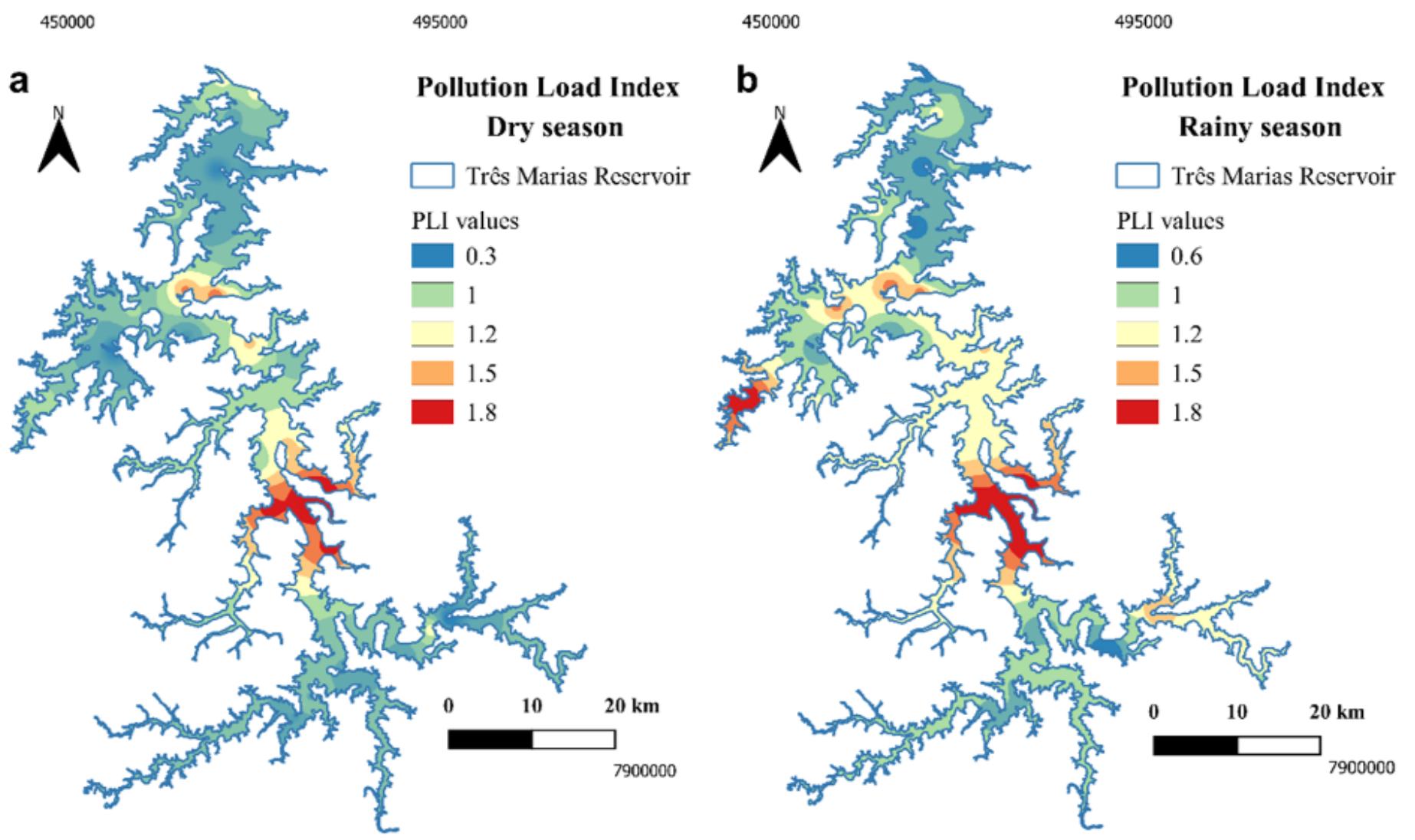

\section{Figure 9}

Pollution Load Index mapping regarding the two main seasons of the Três Marias Reservoir. (a) - PLI mapping on the dry season; (b) - PLI mapping on the rainy season. 

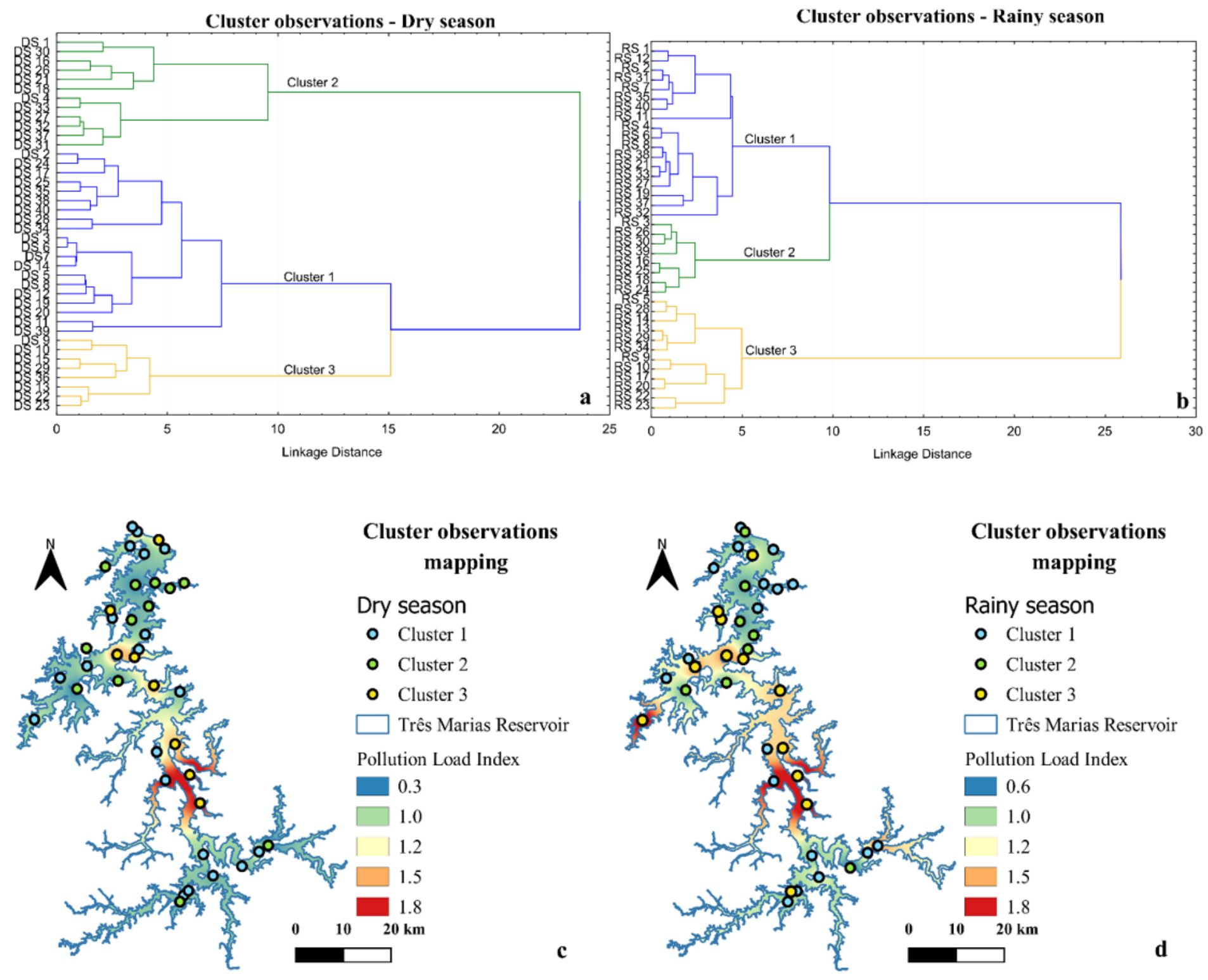

\section{mapping} mapping

ry season

luster 1

uster 2

Cluster 3

Pollution Load Index

1.0

1.5

1.8

c

Figure 10

Clustering observation analysis of dry and rainy seasons obtained the Cluster 1 (blue), Cluster 2 (green), and Cluster 3 (yellow). The three clusters were spatially correlated with the Pollution Load Index mapping for both campaigns. (a) Cluster observation results for the dry season; (b) Cluster observation results for the rainy season; (c) Cluster observations mapping over the PLI index mapping for the dry season; (d) Cluster observations mapping over the PLI index mapping for the rainy season. 